\title{
Effects of Message Strategy and Need for Cognition (NFC) on Consumer Attitudes: A Case of Corporate Social Responsibility (CSR) Advertising
}

\author{
Chao-Ming Yang \\ Department of Visual Communication Design, Ming Chi University of Technology, New Taipei City, Taiwan \\ Email: yangcm@mail.mcut.edu.tw
}

How to cite this paper: Yang, C.-M. (2018) Effects of Message Strategy and Need for Cognition (NFC) on Consumer Attitudes: A Case of Corporate Social Responsibility (CSR) Advertising. Open Journal of Business and Management, 6, 714-732.

https://doi.org/10.4236/ojbm.2018.63055

Received: May 12, 2018

Accepted: July 21, 2018

Published: July 24, 2018

Copyright $\odot 2018$ by author and Scientific Research Publishing Inc. This work is licensed under the Creative Commons Attribution International License (CC BY 4.0).

http://creativecommons.org/licenses/by/4.0/

(c) (i) Open Access

\begin{abstract}
Corporate social responsibility (CSR) advertising can differentiate brands and create product value, and an appropriate messaging strategy can help corporations launch persuasive CSR advertisements. This study employed a $2 \times 2$ mixed experimental design to operate two independent variables-message strategy of CSR advertising (CSR-informational advertising vs. CSR-transformational advertising) and the level of need for cognition (high-NFC vs. low-NFC) - in order to examine the effect of these variables on consumers' attitudes toward advertising and brands. Three primary conclusions were reached: 1) the message strategy of CSR advertising influenced consumers' attitudes toward advertising and brands; 2) NFC levels influenced consumers' attitudes toward advertising and brands; and 3) individuals with high NFC exhibited more positive attitudes toward advertisements and brands in the CSR-informational advertising compared with those in the CSR-transformational advertising. Overall, using advertising to promote CSR activities can strengthen corporate image, promote consumer behavior, and consolidate consumers' brand loyalty; however, corporations must actively consider how to appropriately design CSR advertising content.
\end{abstract}

\section{Keywords}

Corporate Social Responsibility Advertising, Message Strategy, Need for Cognition, Consumer Attitude

\section{Introduction}

In the past decade, companies have gradually directed more attention on corpo- 
rate social responsibility (CSR), using it as a sales strategy for competing in the corporate market [1] [2]. Publicizing CSR information helps companies move toward their sustainable development targets while also successfully positioning themselves and achieving market differentiation [3] [4]. Pomering, Johnson, and Noble [5] reported that increases in CSR advertising are a result of the public's particular emphasis on companies' external image. Previous corporate image advertising models are now embodied by CSR advertising. However, the content of CSR advertising is broader and more practical than corporate image advertising; moreover, CSR advertising tends to focus on the efforts a corporation made in the public domain rather than its sales or profits [6]. However, the motivation behind corporate CSR activities is often sales promotion and profit making; the public is simply unaware of this because of the manner in which CSR advertising is packaged.

In the current consumer market, the external reputation and intrinsic brand equity of a corporation not only distinguish the products and services of one corporation from those of its competitors [7], but also indicate product and corporate status in the consumer market. These characteristics serve as threads that lead consumers into making purchases [8], and the promotion, and implementation of CSR activities is an advertising strategy that many scholars believe can effectively achieve brand differentiation and establish product value [9] [10]. According to one study, 77\% of leading European and American corporations listed CSR activities as an important part of their marketing strategy [11]. Mögele and Tropp noted that between 2002 and 2007, printed advertising related to CSR in magazines in Germany grew by $400 \%$-an amazing growth rate. In addition, Jahdi and Acikdilli [12] revealed that numerous banks in the United Kingdom used CSR to appeal to customer preferences, thereby creating a unique selling proposition in order to attract consumers.

Regardless of whether CSR advertising is in video or print formats, all such advertising involves the formulation of message strategies [13] and how individuals process such messages [14]. However, past studies on CSR advertising have yielded little in-depth discussion on message strategies. Because CSR has grown in importance, further exploration of the persuasiveness of CSR advertising is necessary, specifically in terms of the use of message strategies. In addition, consumers' motivation for information processing influences the effectiveness of advertising [15] [16]. Variation comes from differences in the Need for Cognition (NFC) Scale of consumers [17]. According to the elaboration likelihood model (ELM) [18], consumers follow their motivations and abilities to process messages; the central route leads consumers to process information rationally and objectively, whereas the peripheral route leads consumers to process messages in an emotional and subjective manner [19]. These two paths are in fact closely related to the message strategy. However, research on CSR has rarely explored this topic. Thus, the study had three primary research objectives:

- Discuss how message strategy in CSR advertising affects consumer attitudes. 
- Discuss how NFC in CSR advertising affects consumer attitudes.

- Discuss how message strategy and NFC in CSR advertising interact to affect consumer attitudes.

\section{Theoretical Background}

\subsection{CSR Communication through Advertising}

The concept of CSR originated from corporations actively donating money to charity in the late 19th century [20]. As this trend evolved over time, consumer awareness of such acts of CSR gradually increased; corporations were no longer expected to only sell products but should also shoulder certain social responsibilities [17]. Thus, CSR advertising can draw public recognition and attention to a corporation. Kotler and Lee [21] defined five types of CSR-related message communication patterns. The patterns are as follows: 1) cause promotion-focusing on spreading social or environmental knowledge to encourage consumer interest in a topic; 2) cause-related marketing-donating a portion of revenue to a particular public interest group to motivate consumers to support sales activities; 3 ) corporate social marketing-enhancing the emphasis placed on social and environmental affairs to change consumers' purchasing behavior; 4) corporate philanthropy-donating to public interest groups to improve the lives of disadvantaged people; 5) corporate volunteerism-inviting members of the community or company employees to participate in volunteer work to establish an external corporate reputation. These five types of CSR message strategy are common in modern advertising, and they are frequently used by most business owners.

According to Morsing [22], CSR communication is any message showing the results of CSR-related activities that is designed by a corporation to demonstrate their positive efforts. Ásványi [23] proposed that among numerous types of CSR communication tools, CSR advertising was the most efficient for communicating with the public. CSR advertising refers to the use of text, symbols, or images in mass media advertisements-either directly or implicitly-to indicate the contribution of a corporation made to a moral cause (e.g., social responsibility, environmental conditions, or community outreach). Such advertisements do not directly promote the company's products [24] [25]. Studies have revealed that CSR advertising have been recognized by entrepreneurs and scholars to effectively enhance the positive image of corporations [26] [27]; thus, numerous corporations have actively drafted advertising strategies related to CSR. Bortree et al. [28] analyzed advertisements in National Geographic published from 1979 to 2008 and noted that the advertisements gradually changed from commercial topics to the sustainable development of enterprises, the society, and the environment. This indicates that CSR has become a key advertising strategy in today's consumer market.

\subsection{Message Strategy in CSR Advertising}

Message strategy is defined as a guiding approach to a company's or institution's 
promotional communication efforts for its products, its services, or itself [29]. Message strategy can be divided into informational and transformational types [30]. Informational strategies focus messages on product attributes and efficient performance, whereas transformational strategies are based on the emotional affect, hedonism, and the experiential side of consumption. Scholars have identified these two message strategies as the most basic categorization of advertising creative strategies [31]. In addition, Taylor [29] employed the six-segment message strategy wheel model to analyze advertisements in which two advertising approaches were defined transmission view and ritual view. Researchers consider the transmission view approach to be similar to informational strategy, whereas the ritual view approach is similar to transformational strategy [31]; both approaches induce consumers to generate different message processing patterns and affect subsequent emotional responses and consumer behaviors [32].

In the framework of message strategy proposed by Chiou [13], a value-expressive message pattern creates an image of the product user in the message for consumers; this type of messaging is similar to transformational advertising. By comparison, practicality message pattern informs consumers of certain key benefits, raising consumers' awareness of the functionality or importance of products (services); this is considered informational advertising. From an advertising psychology perspective, an informational message strategy guides consumers to evaluate advertising content through a system of cognition or logic, whereas a transformational message strategy guides consumers to evaluate advertising content through a system of emotion or sense. These two message strategies influence the persuasiveness of advertising [33]. Developing appropriate message strategies in CSR advertising can help companies establish a clear corporate image and market position and communicate ideas to target consumers or stakeholders [34]. The more information about corporate commitment to CSR provided in a CSR advertising message, the stronger the persuasiveness of the advertising message is; consequently, consumers are more inclined to provide a favorable brand assessment [5]. Because CSR advertising largely focuses on public welfare, this study hypothesized that consumers would prefer informational advertising to transformational advertising because the former enables them to identify what tasks a company has undertaken for social welfare and environmental protection. Therefore, the following hypotheses were proposed:

- Hypothesis 1a: Message strategies for CSR advertising influence consumers' advertising attitudes, and consumers demonstrate more positive attitudes toward informational advertisements compared with transformational advertisements.

- Hypothesis 1b: Message strategies for CSR advertising influence consumers' brand attitude, and consumers demonstrate more positive attitudes toward informational advertisements compared with transformational advertisements. 


\subsection{Effect of NFC}

The factors that influence the persuasiveness of advertising have long been a topic of interest for scholars of advertising and marketing. Among these, NFC is a crucial factor related to personal cognitive psychology and behavioral patterns [35]. Cacioppo, Petty, and Kao [17] interpreted NFC as differences among individuals in their tendency to engage in cognitive activities and enjoy thinking, particularly regarding their intrinsic motivation and preference level. The level of an individual's NFC is the most essential factor affecting motivation in message processing. Levin, Haugtvedt, and Petty [36] noted that a message alone does not actively convince consumers; the persuasiveness of the message entirely depends on an individual's initial motivation in message processing. In fact, motivation in processing messages is a distinctive feature of cognitive psychology [14]. Numerous studies of consumer behavior have revealed that when consumers are exposed to an advertising message, differences in NFC lead them to perform different levels of message processing on the advertising appeals [37]. Therefore, some scholars have argued that that the level of consumers' NFC and the manner in which advertising messages are processed are closely related [38]. Based on the aforementioned research, this study proposed the following hypotheses:

- Hypothesis 2a: NFC levels influence consumers' attitudes toward CSR advertising, and high-NFC individuals demonstrate more positive attitudes than low-NFC individuals.

- Hypothesis 2b: NFC influences consumers' attitudes toward CSR brand, and high-NFC individuals demonstrate more positive attitudes than low-NFC individuals.

Haugtved and Petty [36] noted that high-NFC individuals prefer thinking and forming brand attitudes through cognitive thinking; conversely, low-NFC individuals dislike analyzing advertising messages; therefore, they are more susceptible to clues other than primary information (e.g., pictures, spokespeople, and stories). Bata and Stayman [39] confirmed that low-NFC individuals preferred using intuitive methods to process advertising messages. Zhang and Buda [38] further explained that variations of NFC determine whether consumers exhibit the ability and desire to make cognitive responses to the content of advertising messages. Moreover, according to the ELM, when advertising messages are revealed in the media, consumers' attitudes and responses to information scrutiny directly affect their information processing [40]. As a result, the process of receiving and processing advertising messages is related to the results of consumers' personal cognitive reactions [41]. Petty and Cacioppo [19] further argued that both motivation and ability to process information affect consumers' choices when processing the content of received messages. If the receiver has both the motivation and ability to process the message, the receiver's relative involvement will be higher, leading them to adopt the central route message processing approach. If the receiver lacks the both the motivation and ability to process the message, the receiver's relative involvement will be lower, leading them to adopt 
the peripheral route message processing approach. Based on the aforementioned research, this study proposed the following hypotheses:

- Hypothesis 3a: High-NFC individuals have more positive attitudes toward the advertisements in CSR-informational advertising compared with those in CSR-transformational advertising.

- Hypothesis 3b: High-NFC individuals have more positive attitudes toward the brands in CSR-informational advertising compared with those in CSR-transformational advertising.

- Hypothesis 4a: Low-NFC individuals have more positive attitudes toward the advertisements in CSR-transformational advertising compared with those in CSR-informational advertising.

- Hypothesis 4b: Low-NFC individuals have more positive attitudes toward the brands in CSR-transformational adverting compared with those in CSR-informational advertising.

\section{Research Method}

\subsection{Experimental Variables}

Based on Taylor [29], this study used message strategy as the first independent variable. In Lee et al. [30], message strategies of CSR advertising were divided into two types: CSR-informational advertising-which uses textual descriptions to publicize CSR efforts; and CSR-transformational advertising-which highlights a single story to publicize CSR.

According to the work of Cacioppo et al. [17], NFC was set as the second independent variable and tested using the NFC scale (NCS). The scale examines respondents' level of NFC; based on their scores on the scale, respondents are classified as high-NFC individuals or low-NFC individuals. High-NFC individuals repeatedly deliberate and analyze received messages and prefer solving complex problems; they are satisfied by rational thinking. Low-NFC individuals are unlikely to repeatedly deliberate and analyze received messages and prefer simple problem-solving methods; they are satisfied by initiative thinking.

Research has indicated that the persuasiveness of advertising can be demonstrated by changes in consumer attitude following the stimulation of advertising messages [42]. Therefore, consumers' attitudinal inclination after receiving advertising messages can be used to examine the persuasiveness of an advertisement's message [14] [43]. Based on the aforementioned research, this study set attitudes toward the ad $\left(\mathrm{A}_{\mathrm{ad}}\right)$ and attitudes toward the brand $\left(\mathrm{A}_{\mathrm{b}}\right)$ as dependent variables. $A_{a d}$ represented consumers' overall reaction to advertising after receiving the advertising message; $A_{b}$ represented consumers' overall impression of the product brand in the advertisement after receiving advertising messages [44] (Table 1).

\subsection{Pretest Questionnaire}

The NFC dimension was rated using a 7-point Likert scale $(1=$ extremely un- 
characteristic; $7=$ extremely characteristic). The scale had a total of 18 items ( 9 positive and 9 negative items) (see Appendix). For $\mathrm{A}_{\mathrm{ad}}$, 7 -point scale of semantic differential method was employed. The five pairs of bipolar opposition adjectives used for this dimension were as follows [45] [46]: good/bad, like/dislike, pleasant/unpleasant, favorable/unfavorable, and interesting/boring. For $A_{b}$, the scales comprised 7 levels of semantic differential. The scale of this dimension also used five pairs of bipolar opposition adjectives [14] [47]: good/bad, like quite a lot/dislike quite a lot, pleasant/unpleasant, good quality/poor quality, and nice/not nice.

Before the official experiment, 40 college students were selected for a pretest conducted using CSR advertising videos for Google Chrome. Cronbach's alpha tests revealed that the internal consistency reliability of the NCS was $\alpha=0.87$; the internal consistency reliability of $\mathrm{A}_{\mathrm{ad}}$ was $\alpha=0.886$; and the internal consistency reliability of $\mathrm{A}_{\mathrm{b}}$ was $\alpha=0.86$. The three dimensions all demonstrated a high level of reliability with results greater than 0.7 .

\subsection{Experiment Design and Stimuli}

This study employed a $2 \times 2$ mixed experimental design to test the two variables, CSR advertising message strategies (CSR-informational advertising vs. CSR-transformational advertising) and the level of NFC (high NFC vs. low NFC). CSR advertising videos were collected from the Internet, and message strategy types were identified following the operational definition. Subsequently, three experts selected four appropriate advertisements according to the experimental requirements. The selected advertisements were used for the experimental stimuli and experimental conditions (A-D) (Table 2).

Table 1. The description of experimental variables.

\begin{tabular}{|c|c|c|}
\hline \multicolumn{2}{|c|}{ Experimental Variables } & \multirow{2}{*}{$\begin{array}{l}\text { Description of Variables } \\
\text { The advertising uses textual descriptions to publicize } \\
\text { CSR efforts. }\end{array}$} \\
\hline & $\begin{array}{l}\text { CSR-informational } \\
\text { advertising }\end{array}$ & \\
\hline & $\begin{array}{l}\text { CSR-transformational } \\
\text { advertising }\end{array}$ & $\begin{array}{l}\text { The advertising highlights a single story to publicize } \\
\text { CSR efforts. }\end{array}$ \\
\hline \multirow[t]{2}{*}{$\begin{array}{l}\text { Independent } \\
\text { Variables }\end{array}$} & High-NFC individuals & $\begin{array}{l}\text { The individuals repeatedly deliberate and analyze } \\
\text { received messages and prefer solving complex } \\
\text { problems; they are satisfied by rational thinking. }\end{array}$ \\
\hline & Low-NFC individuals & $\begin{array}{l}\text { The individuals are unlikely to repeatedly deliberate } \\
\text { and analyze received messages and prefer simple } \\
\text { problem-solving methods; they are satisfied by } \\
\text { initiative thinking. }\end{array}$ \\
\hline \multirow{2}{*}{$\begin{array}{l}\text { Dependent } \\
\text { Variables }\end{array}$} & $\begin{array}{l}\text { Attitudes toward the ad } \\
\left(\mathrm{A}_{\mathrm{ad}}\right)\end{array}$ & $\begin{array}{l}\text { The attitudes represented consumers' overall reaction } \\
\text { to advertising after receiving the advertising message. }\end{array}$ \\
\hline & $\begin{array}{l}\text { Attitudes toward the } \\
\text { brand }\left(A_{b}\right)\end{array}$ & $\begin{array}{l}\text { The attitudes represented consumers' overall } \\
\text { impression of the product brand in the advertisement } \\
\text { after receiving advertising messages. }\end{array}$ \\
\hline
\end{tabular}


Table 2. The description of experiment stimuli (Source: Yang \& Hsu, 2017).

\begin{tabular}{|c|c|c|c|}
\hline $\begin{array}{l}\text { Message Strategy of CSR } \\
\text { advertising }\end{array}$ & $\begin{array}{l}\text { Corporative } \\
\text { Name }\end{array}$ & Description of CSR Advertising Content & $\begin{array}{l}\text { Experiment } \\
\text { Condition }\end{array}$ \\
\hline \multirow{2}{*}{$\begin{array}{l}\text { CSR-informational } \\
\text { advertising }\end{array}$} & Starbucks & $\begin{array}{l}\text { This video describes Starbucks fulfilling its CSR by showing concern to the growing } \\
\text { environments for Arabica coffee beans and forming partnerships with coffee farmers. } \\
\text { Through ethical sourcing, Starbucks plans to give back to local communities by } \\
\text { establishing medical facilities in these communities and providing complete learning } \\
\text { environments for children. In addition, Starbucks adopts a discount approach to } \\
\text { encourage customers to use their own reusable cups when purchasing a drink, thereby } \\
\text { reducing environmental pollution. Starbucks stores are also equipped with LED lights, } \\
\text { which save roughly } 30 \% \text { of energy per year. The company further advocates water } \\
\text { conservation by recycling rainwater, uses coffee grounds as fertilizer, and encourages } \\
\text { that each staff member participate in no less than eight hours of environmental } \\
\text { volunteer work per year. }\end{array}$ & Condition A \\
\hline & Nike & $\begin{array}{l}\text { In this video, Nike discovered that over a quarter of the forests in South Asian countries } \\
\text { have been cut down illegally to manufacture sport shoes. Nike also found that the } \\
\text { laborers of a number of factories were only allowed a day of leave per week, with } 50 \% \\
\text { working over } 60 \text { hours. Some families even allowed their underage children to work in } \\
\text { the factories. To fulfil its CSR, Nike decided to implement an improvement project for } \\
\text { production. Through the implementation of its CSR project, the relationship between } \\
\text { customers, suppliers, investors, and competitors gradually changed. These changes } \\
\text { effectively reduced the work time of the South Asian laborers, alleviated the problem of } \\
\text { underage labor and illiteracy problems, and fulfilled its green environment } \\
\text { responsibilities. }\end{array}$ & Condition B \\
\hline \multirow{2}{*}{$\begin{array}{l}\text { CSR-transformational } \\
\text { advertising }\end{array}$} & Coca-Cola & $\begin{array}{l}\text { This video describes that thousands of South Asian laborers arrive in Dubai to work } \\
\text { every day to provide a better life for their families. These South Asian laborers travel far } \\
\text { away from their homes to Dubai to work. They are often unable to pay for expensive } \\
\text { telephone fees and loose contact with their families. To fulfil its CSR, Coca-Cola } \\
\text { designed a public telephone booth that uses Coke bottle caps as currency. Using this } \\
\text { telephone booth, laborers are able to connect with their family members without having } \\
\text { to pay a fee and receive a moment of happiness. }\end{array}$ & Condition C \\
\hline & Samsung & $\begin{array}{l}\text { This video describes that many villages in Ethiopia have not yet received electricity due } \\
\text { to a poor economy riddled with poverty. These villages have never used a light. When } \\
\text { the sun sets, the villages become dark and the villagers cannot do anything besides wait } \\
\text { for the day. To fulfil its CSR, Samsung designed and donated solar lanterns to the } \\
\text { villagers. Using these solar lanterns, the villagers were able to continue producing } \\
\text { traditional handcrafts at night to increase their family income, improve their quality of } \\
\text { life, and provide a better education for their children. }\end{array}$ & Condition D \\
\hline
\end{tabular}

\subsection{Participants and Experimental Conditions}

This study applied purposive sampling to select undergraduate and graduate students from departments of applied foreign languages, business administration, industrial design, and visual design at four universities in Taiwan. Four experimental conditions were selected-A through D-and each experimental condition was tested twice collectively. A total of 80 participants were assigned for each test, and a total of 320 participants were enrolled (male $=152$, female $=$ 168). The participants ranged in age from 20 to 27 years (mean: 24.8 years). Among the participants, 77 (24.1\%) were from departments of applied foreign languages; 83 (25.9\%) were from departments of business administration; 82 (25.6\%) were from departments of industrial design; and 78 (24.4\%) were from departments of visual art design (Table 3 ). 
Table 3. Distribution of participants in experimental conditions.

\begin{tabular}{|c|c|c|c|c|c|c|}
\hline & & \multicolumn{4}{|c|}{ Experimental Conditions } & \multirow[b]{2}{*}{ Total } \\
\hline & & A & $\mathrm{B}$ & $\mathrm{C}$ & $\mathrm{D}$ & \\
\hline \multirow{5}{*}{$\begin{array}{l}\text { Participant's } \\
\text { background }\end{array}$} & Applied foreign languages & 20 & 19 & 20 & 18 & 77 \\
\hline & Business administration & 20 & 21 & 20 & 22 & 83 \\
\hline & Industrial design & 21 & 20 & 21 & 20 & 82 \\
\hline & Visual art design & 19 & 20 & 19 & 20 & 78 \\
\hline & Total & 80 & 80 & 80 & 80 & 320 \\
\hline
\end{tabular}

\subsection{Sample Distribution of NFC}

This study employed the post-clustering method used by Meyers-Levy and Malaviya [41] to sum up the scores of NCS, and the median was used as the basis for differentiating samples [36]. Data analysis revealed that the number of high-NFC individuals was $154(48.1 \%, M=84.31$, range $=78-113)$ and the number of low-NFC individuals was $166(51.9 \%, M=59.81$, range $=43-77)$. The detailed sample size distribution is summarized in Table 4.

Data were imported into the SPSS statistical software. Verifying the internal consistency reliability revealed that the Cronbach's alpha of the high-NFC group was $\alpha=0.89$ and that of the low-NFC group was $\alpha=0.92$. Thus, the two groups exhibited high reliability (greater than 0.70 ). Subsequently, an independent sample $\mathrm{t}$ test was employed to confirm the difference between the two groups; the results showed that $t(318)=28.39$ and reached a significance level of $p<0.001$ $(p=0.000)$. Thus, the two sample groups were indeed different and suitable for the examination of the second independent variable. Additionally, the data of $\mathrm{A}_{\mathrm{ad}}$ and $\mathrm{A}_{\mathrm{b}}$ were also verified using Cronbach's alpha, and their internal consistency reliability was $\alpha=0.91$ and $\alpha=0.92$, respectively. Both variables also demonstrated a high reliability (greater than 0.70 ).

\section{Data Analysis}

Independent samples $t$ tests were used to determine the effect of CSR advertising message strategies and NFC on $A_{a d}$ and $A_{b}$, respectively. For the effect of CSR advertising message strategy on $\mathrm{A}_{\mathrm{ad}}, t(318)=2.09$ and reached a significance level of $p<0.05\left(M_{\text {CSR-information }}=4.10>M_{\text {CSR-transformation }}=3.83, p=0.037\right)$; for the effect of NFC on $\mathrm{A}_{\mathrm{ad}}, t(318)=-2.11$ and reached a significance level of $p<0.05$ $\left(M_{\text {high-NFC }}=4.09>M_{\text {low-NFC }}=3.83, p=0.036\right)$. For the effect of CSR advertising message strategy on $\mathrm{A}_{\mathrm{b}}, t(318)=2.58$ and reached a significance level of $p<0.05$ $\left(M_{\text {CSR-information }}=4.18>M_{\text {CSR-transformation }}=3.86, p=0.01\right)$; for the effect of NFC on $\mathrm{A}_{\mathrm{b}}, t(318)=-2.05$ and reached a significance level of $p<0.05\left(M_{\text {high-NFC }}=4.13>\right.$ $\left.M_{\text {low-NFC }}=3.88, p=0.041\right)$ (Table 5).

Subsequently, two-way analysis of variance revealed that the $F$ values of the two independent variables corresponding to the dependent variables $(\mathrm{A} \times \mathrm{B})$ all reached a significance level of $p<0.01\left(\mathrm{~A}_{\mathrm{ad}}: F=17.88, p=0.000 ; \mathrm{A}_{\mathrm{b}}: F=12.12, p\right.$ 
$=0.001)$. These results indicated that the two independent variables caused the interactive effect between participants' attitudes toward the advertisements and brands (Table 6). In addition, a simple main effect significance test was conducted, which indicated that the difference in CSR advertising message strategy had a significant effect on the $\mathrm{A}_{\mathrm{ad}}$ of the high-NFC individuals $(F(1,152)=30.17$, $p<0.001, \eta^{2}=0.21$ ). The high-NFC individuals' attitudes toward advertisements in the CSR-informational advertising outperformed the CSR-transformational advertising $\left(M_{\mathrm{CSR} \text {-information }}=4.24>M_{\mathrm{CSR} \text {-transformation }}=3.43\right)$. Differences in CSR advertising message strategies also had a significant effect on the $\mathrm{Ab}$ of the high-NFC individuals $\left(F(1,152)=20.79, p<0.001, \eta^{2}=0.17\right)$. The high-NFC individuals' attitudes toward brands in the CSR-informational advertising also outperformed the CSR-transformational advertising $\left(M_{\text {CSR-information }}=4.27>\right.$ $M_{\text {CSR-transformation }}=3.53$ ). For the low-NFC individuals, neither their attitudes toward $A_{a d}$ nor their attitudes toward $\mathrm{Ab}$ reached the significance level of $p<0.05$ (Table 7).

Table 4. Distribution of participants by NFC individuals score.

\begin{tabular}{ccccccc}
\hline & & \multicolumn{5}{c}{ Experimental Conditions } \\
\cline { 3 - 7 } & & \multicolumn{2}{c}{$\begin{array}{c}\text { CSR-informational } \\
\text { advertising }\end{array}$} & $\begin{array}{c}\text { CSR-transformational } \\
\text { advertising }\end{array}$ \\
\cline { 3 - 7 } & & Condition A & Condition B & Condition C & Condition D & Total \\
\hline \multirow{2}{*}{\begin{tabular}{c} 
Infividuals \\
\cline { 3 - 6 }
\end{tabular}} & High-NFC & 44 & 41 & 33 & 36 & 154 \\
& Low-NFC & 36 & 39 & 47 & 44 & 166 \\
\hline
\end{tabular}

Table 5. Distribution of participants by NFC individuals score.

\begin{tabular}{|c|c|c|c|c|c|c|}
\hline \multirow{2}{*}{\multicolumn{2}{|c|}{ Variables Source }} & \multirow[b]{2}{*}{$n$} & \multicolumn{2}{|c|}{$\begin{array}{l}\text { Attitudes toward the ad } \\
\qquad\left(\mathrm{A}_{\mathrm{ad}}\right)\end{array}$} & \multicolumn{2}{|c|}{$\begin{array}{l}\text { Attitudes toward the } \\
\text { brand }\left(A_{b}\right)\end{array}$} \\
\hline & & & $M$ & Std. & $M$ & Std. \\
\hline \multirow{2}{*}{$\begin{array}{l}\text { Message strategies of } \\
\text { CSR advertising }\end{array}$} & CSR-information & 160 & 4.10 & 1.10 & 4.18 & 1.12 \\
\hline & CSR-transformation & 160 & 3.83 & 1.19 & 3.86 & 1.03 \\
\hline \multirow{2}{*}{ NFC individuals } & High-NFC & 154 & 4.09 & 1.02 & 4.13 & 1.09 \\
\hline & Low-NFC & 166 & 3.82 & 1.27 & 3.88 & 1.08 \\
\hline
\end{tabular}

Table 6. Effects of message strategies of CSR advertising and NFC individuals on Aad and $\mathrm{Ab}$.

\begin{tabular}{ccccccc}
\hline Variables Source & SS & df & MS & $F$ & Sig. \\
\hline Attitudes toward the ad $\left(\mathrm{A}_{\mathrm{ad}}\right)$ & & & & & \\
Message strategies of CSR advertising (A) & 6.35 & 1 & 6.35 & 5.10 & $0.25^{*}$ \\
NFC individuals (B) & 5.57 & 1 & 5.57 & 4.48 & $0.35^{*}$ \\
A $\times$ B & 22.23 & 1 & 22.23 & 17.88 & $0.000^{* * *}$ \\
\hline
\end{tabular}


Continued

\begin{tabular}{ccccccc}
\hline Attitudes toward the brand $\left(\mathrm{A}_{\mathrm{b}}\right)$ & & 1 & & & \\
Message strategies of CSR advertising $(\mathrm{A})$ & 8.28 & 1 & 8.28 & 7.39 & $0.007^{* *}$ \\
NFC individuals (B) & 4.26 & 1 & 4.26 & 4.12 & $0.043^{*}$ \\
$\mathrm{~A} \times \mathrm{B}$ & 13.62 & 1 & 13.62 & 12.17 & $0.001^{* *}$ \\
\hline
\end{tabular}

${ }^{*} \mathrm{p}<0.05,{ }^{* *} \mathrm{p}<0.01,{ }^{* * *} \mathrm{p}<0.001$.

Table 7. Simple main effects of the two independent variables.

\begin{tabular}{|c|c|c|c|c|c|}
\hline Variables Source & $S S$ & $d f$ & $M S$ & $F$ & Sig. \\
\hline \multicolumn{6}{|l|}{ Attitudes toward the ad $\left(\mathrm{A}_{\mathrm{ad}}\right)$} \\
\hline \multicolumn{6}{|c|}{ Message strategies of CSR advertising (A) } \\
\hline in B1 (High-NFC) & 25.22 & 1 & 25.22 & 30.17 & $0.000^{* * *}$ \\
\hline in B2 (Low-NFC) & 2.51 & 1 & 2.51 & 1.55 & 0.216 \\
\hline \multicolumn{6}{|l|}{ NFC individuals (B) } \\
\hline in A1 (CSR-information) & 25.08 & 1 & 25.08 & 19.48 & $0.000^{* * *}$ \\
\hline in A2 (CSR-transformation) & 2.77 & 1 & 2.77 & 2.31 & 0.131 \\
\hline \multicolumn{6}{|l|}{ Attitudes toward the brand $\left(\mathrm{A}_{\mathrm{b}}\right)$} \\
\hline \multicolumn{6}{|c|}{ Message strategies of CSR advertising (A) } \\
\hline in B1 (High-NFC) & 20.79 & 1 & 20.79 & 19.71 & $0.000^{* * *}$ \\
\hline in B2 (Low-NFC) & 0.344 & 1 & 0.344 & 0.292 & 0.590 \\
\hline \multicolumn{6}{|l|}{ NFC individuals (B) } \\
\hline in A1 (CSR-information) & 17.08 & 1 & 17.08 & 17.54 & $0.000^{* * *}$ \\
\hline in A2 (CSR-transformation) & 1.19 & 1 & 1.19 & 0.938 & 0.334 \\
\hline
\end{tabular}

${ }^{*} \mathrm{p}<0.05,{ }^{* *} \mathrm{p}<0.01,{ }^{* *} \mathrm{p}<0.001$.

\section{Discussion}

\subsection{Effects of Message Strategy in CSR Advertising}

CSR advertising message strategy was the first independent variable, and the results showed that CSR advertising message strategy did influence consumers' advertising and brand attitudes, and consumers demonstrated more positive attitudes toward informational advertisements than transformational advertisements. Therefore, hypotheses H1a and H1b were supported.

Expanding on these results, the content of CSR advertisements is usually related to four types of responsibilities, namely economic, juridical, ethical, and philanthropic responsibilities [48]. Many people welcome corporations that are not solely focused on making profit and use nonprofit-seeking methods to contribute to social welfare and environmental protection. Thus, CSR advertising and commercial advertising are profoundly different because CSR advertising is inherently focused on public welfare; this encompasses the aforementioned four social responsibilities. However, CSR advertising usually contains several mis- 
sions; thus, when delivering CSR advertising campaigns, corporations must begin from a multiple-message claim perspective [49]. For multiple-message claim advertising, the communication of advertisements is based on multiple benefits of a commodity and should work together with the message strategy of CSR-informational advertising; consumers are more likely to be cognizant of how a corporation has helped society and the environment as a result of the text used in CSR advertising. This helps explain why consumers demonstrate more favorable attitudes toward advertisements and brands that employ CSR-informational advertising rather than CSR-transformational advertising. In addition, according to the results, the more social responsibilities and obligations are conveyed in the CSR advertising, the higher the consumers' approval for the brand becomes; therefore, CSR-informational advertising appears to be positively related with consumer' attitudes toward advertisements and brands.

\subsection{Effect of NFC in CSR Advertising}

The second independent variable was the level of consumers' NFC. The effect of this independent variable on consumers' advertising and brand attitudes was examined. The results indicated that the level of NFC did influence consumers' advertising and brand attitudes in CSR advertising. High-NFC individuals demonstrated more positive attitudes toward CSR advertisements compared with low-NFC individuals. Therefore, hypotheses H2a and H2b were both supported.

From the results, the author of this study considered that the content of CSR advertising not only promotes public welfare, but also has commercial purposes. Consumers must invest in more message processing capabilities when viewing CSR advertising. Cacioppo et al. [17] also noted that differences in consumers' motivation for message investigation lead to different levels of cognitive responses when dealing with information that requires in-depth processing. This cognitive reaction is particularly clear when consumers are processing complex items. Chang [50] defined this difference in message processing motivation as the difference in the diagnostic capability product information. When consumers diagnose product information, they are more likely to respond to advertising message and brand information. By linking previous research, this study revealed that the level of consumers' NFC can be regarded as a mediating variable that influences the diagnostic capability of product information. Accordingly, the diagnostic capability of product information exists in high-NFC individuals but not in low-NFC individuals. Therefore, the difference in NFC is not only a manifestation of the consumers' NFC styles, but also an indication of their level of message involvement, logical scrutiny, and clue integration. In addition, once a CSR advertisement attracts consumers' attention, consumers seeking to determine the authenticity of the content must invest greater intellectual efforts to follow the CSR advertising message and relationship between products in order to understand the true meaning of the message. This process leads some con- 
sumers (e.g., high-NFC individuals) to investigate the content of CSR advertising from high-involvement perspectives, ultimately affecting consumers' attitudes toward advertisements and brands.

\subsection{Interaction Effect of Message Strategy and NFC in CSR Advertising}

The two independent variables in this study-message strategy and NFC demonstrated interaction effects on the consumers' attitudes toward advertisements and brands. High-NFC individuals demonstrated more positive attitudes toward the advertisements and brands in the CSR-informational advertising compared with those in the CSR-transformational advertising; however, low-NFC individuals' attitudes toward the advertisements and brands in the two types of CSR advertising did not achieve significance. Based on the aforementioned results, hypotheses $\mathrm{H} 3 \mathrm{a}$ and $\mathrm{H} 3 \mathrm{~b}$ were supported and $\mathrm{H} 4 \mathrm{a}$ and $\mathrm{H} 4 \mathrm{~b}$ were not supported.

Analyzing the results, most CSR advertisements are related to the marketing strategy of cause-related marketing (CRM) [51]; that is, by undertaking certain social responsibilities and publicizing the results through news media and advertising campaigns, corporations attempt to enhance their corporate image and brand awareness in order to increase sales [52]. In fact, some consumers do not trust CRM because they suspect that the motivation of corporations implementing CSR is related to CRM; that is, these corporations use the pretext of public welfare to sell their goods. This skepticism is clearly demonstrated in low-NFC consumers. In addition, based on the ELM [40], high-NFC individuals are more willing to accept complex and challenging tasks; that is, they are inclined to examine message content and process messages in depth following the central route. Such individuals simultaneously generate positive attitudes (e.g., happiness and pleasure) by processing related messages. Conversely, low-NFC individuals tend to accept simple tasks that are highly consistent in nature and follow the peripheral route to demonstrate their attitudes toward messages. Consequently, they are susceptible to irrelevant messages.

In summary, the message strategy of CSR-informational advertising requires consumers to learn from the cognition or logic system and carefully evaluate the authenticity of advertising content and CSR activities. This type of message transmission follows the central route of cues and is also consistent with the thinking pattern of high-NFC individuals. Therefore, such individuals transfer positive attitudes toward advertisements to brands while viewing CSR-informational advertising. However, in this experiment, even though the CSR advertisements were designed to appeal to consumers, they still failed to effectively enhance the positive attitudes of low-NFC individuals. This revealed that low-NFC individuals do not trust CSR advertising.

\section{Conclusions}

Modern technological advancements have actuated the prevalence of Internet media and enhanced readers' and listeners' ability to judge messages. Today, 
consumers are no longer passive receivers of messages. Instead, they actively screen advertisement information. Enterprises manipulate CSR advertising to strengthen their reputation. However, over-manipulating CSR advertising causes readers and listeners to not only disbelieve the advertised content, but also become skeptical towards the enterprise's commitment to supporting public welfare activities. Thus, appropriately using CSR advertising to improve corporate image is a crucial issue for advertisers. Moreover, advertising skepticism has become a protective mechanism for consumers, which guides them in formulating new judgments concerning advertising messages. However, advertising skepticism may also actuate bona fide marketing value. Therefore, the skepticism not only benefits consumers, but also creates positive value in the overall sales market.

Numerous enterprise executives perceive CSR activities as an unavoidable obligation forced onto them by social pressure. This passive CSR management attitude negatively influences the internal cohesion of an enterprise. The present study asserts that instead of passively and occasionally engaging in social welfare activities, enterprise should actively form relevant budget plans and include CSR activities as a marketing plan for the enterprise. These actions are beneficial because the public's evaluation of the CSR efforts of an enterprise is a long-term issue of concern and a linear perception. In other words, readers and listeners are unlikely to place their trust in or praise an enterprise for its occasional efforts in social welfare. Therefore, enterprises should not only focus on the short-term benefits of CSR when formulating CSR or relevant advertisements. Otherwise, consumers will inevitably unveil the deception. This phenomenon is similar to a Chinese proverb that states, "Distance tests a horse's stamina, and time reveals a man's heart."

\section{Acknowledgements}

The author gratefully acknowledges the support for this research provided by the Ministry of Science and Technology of Taiwan under Grants No. MOST-106-2410-H-131-002.

\section{References}

[1] Alcañiz, E.B., Caceres, R.C. and Perez, R.C. (2010) Alliances between Brands and Social Causes: The Influence of Company Credibility of Social Responsibility Image. Journal of Business Ethics, 96, 169-186. https://doi.org/10.1007/s10551-010-0461-x

[2] Becker-Olsen, K., Cudmore, A. and Hill, R. (2006) The Impact of Perceived Corporate Social Responsibility on Consumer Behavior. Journal of Business Research, 59, 46-53. https://doi.org/10.1016/j.jbusres.2005.01.001

[3] Pirsch, J., Gupta, S. and Grau, S.L. (2007) A Framework for Understanding Corporate Social Responsibility Programs as a Continuum: An Exploratory Study. Journal of Business Ethics, 70, 125-140. https://doi.org/10.1007/s10551-006-9100-y

[4] Bansal, P. and Clelland, I. (2004) Talking Trash: Legitimacy, Impression Management, and Unsystematic Risk in the Context of the Natural Environment. Academy 
of Management Journal, 47, 93-103. https://doi.org/10.5465/20159562

[5] Livesey, S.M. and Dearins, K. (2002) Transparent and Caring Corporations? A Study of Sustainability Reports by the Body Shop and Royal Dutch/Shells. Organization and Environment, 15, 233-258. https://doi.org/10.1177/1086026602153001

[6] Pomering, A., Johnson, L.W. and Noble, G. (2013) Advertising Corporate Social Responsibility: Results from an Experimental Manipulation of Key Message Variables. Corporate Communications: An International Journal, 18, 249-263. https://doi.org/10.1108/13563281311319517

[7] Rossiter, J.R. and Bellman, S. (2005) Marketing Communications: Theory and Applications. Australasian Marketing Journal, 13, 77-80. https://doi.org/10.1016/S1441-3582(05)70081-1

[8] McEnally, M. and De Chernatony, L. (1999) The Evolving Nature of Branding: Consumer and Managerial Considerations. Academy of Marketing Science Review, 2, 1-16.

[9] Erdem, T. and Swait, J. (1998) Brand Equity as a Signaling Phenomenon. Journal of Consumer Psychology, 7, 131-157. https://doi.org/10.1207/s15327663jcp0702_02

[10] Brammer, S. and Millington, A. (2006) Firm Size, Organizational Visibility and Corporate Philanthropy: An Empirical Analysis. Business Ethics: A European Review, 15, 6-18. https://doi.org/10.1111/j.1467-8608.2006.00424.x

[11] Du, S., Bhattacharya, C.B. and Sen, S. (2010) Maximizing Business Returns to Corporate Social Responsibility (CSR): The Role of CSR Communication. International Journal of Management Reviews, 12, 8-19. https://doi.org/10.1111/j.1468-2370.2009.00276.x

[12] Mögele, B. and Tropp, J. (2010) The Emergence of CSR as an Advertising Topic: A Longitudinal Study of German CSR Advertisements. Journal of Marketing Communications, 16, 163-181. https://doi.org/10.1080/13527260802648359

[13] Jahdi, K.S. and Acikdilli, G. (2009) Marketing Communications and Corporate Social Responsibility (CSR): Marriage of Convenience or Shotgun Wedding? Journal of Business Ethics, 88, 103-113. https://doi.org/10.1007/s10551-009-0113-1

[14] Chiou, J.S. (2002) The Effectiveness of Different Advertising Message Appeals in the Eastern Emerging Society: Using Taiwanese TV Commercials as an Example. International Journal of Advertising, 21, 217-236. https://doi.org/10.1080/02650487.2002.11104927

[15] Martin, B.A.S., Lang, B. and Wong, S. (2003) Conclusion Explicitness in Advertising: The Moderating Role of Need for Cognition (NFC) and Argument Quality (AQ) on Persuasion. Journal of Advertising, 32, 57-66. https://doi.org/10.1080/00913367.2003.10639148

[16] Chebat, J.C., Charlebois, M. and Gélinas-Chebat, C. (2001) What Makes Open vs. Closed Conclusion Advertisements More Persuasive? The Moderating Role of Prior Knowledge and Involvement. Journal of Business Research, 53, 93-102. https://doi.org/10.1016/S0148-2963(99)00078-8

[17] Sawyer, A.G. and Howard, D.J. (1991) Effects of Omitting Conclusions in Advertisements to Involved and Uninvolved Audiences. Journal of Marketing Research, 28, 467-474. https://doi.org/10.2307/3172786

[18] Cacioppo, J.T., Petty, R.E. and Kao, C.F. (1984) The Efficient Assessment of Need for Cognition. Journal of Personality Assessment, 48, 306-307. https://doi.org/10.1207/s15327752jpa4803_13

[19] Cacioppo, J.T., Petty, R.E., Kao, C.F. and Rodriguez, R. (1986) Central and Peripheral Routes to Persuasion: An Individual Difference Perspective. Journal of Per- 
sonality and Social Psychology, 51, 1032-1043. https://doi.org/10.1037/0022-3514.51.5.1032

[20] Petty, R.E. and Cacioppo, J.T. (1986) The Elaboration Likelihood Model of Persuasion. In: Communication and Persuasion, Springer, New York, 1-24.

[21] Van Marrewijk, M. (2003) Concepts and Definitions of CSR and Corporate Sustainability: Between Agency and Communion. Journal of Business Ethics, 44, 95-105. https://doi.org/10.1023/A:1023331212247

[22] Kotler, P. and Lee, N. (2008) Corporate Social Responsibility: Doing the Most Good for Your Company and Your Cause. John Wiley \& Sons, New York.

[23] Morsing, M. (2006) Corporate Social Responsibility as Strategic Auto-Communication: On the Role of External Stakeholders for Member Identification. Business Ethics: $A$ European Review, 15, 171-182. https://doi.org/10.1111/j.1467-8608.2006.00440.x

[24] Ásványi, K. (2009) CSR Communication of a Large Bank. Proceedings of Marketing Faculty Club, 15, 25-26.

[25] Karunamoorthy, S. and Mutharasu, S.A. (2012) Reactions on Corporate Social Responsibility Print Advertising of Indian Oil. International Journal of Exclusive Management Research, 2, 1-12.

[26] Perks, K.J., Farache, F., Shukla, P. and Berry, A. (2013) Communicating Responsibility-Practicing Irresponsibility in CSR Advertisements. Journal of Business Research, 66, 1881-1888. https://doi.org/10.1016/j.jbusres.2013.02.009

[27] Maignan, I. and Ferrell, O.C. (2004) Corporate Social Responsibility and Marketing: An Integrative Framework. Journal of the Academy of Marketing Science, 32, 3-19. https://doi.org/10.1177/0092070303258971

[28] Sen, S. and Bhattacharya, C.B. (2001) Does Doing Good Always Lead to Doing Better? Consumer Reactions to Corporate Social Responsibility. Journal of Marketing Research, 38, 225-243. https://doi.org/10.1509/jmkr.38.2.225.18838

[29] Bortree, D.S., Ahern, L., Smith, A.N. and Dou, X. (2013) Framing Environmental Responsibility: 30 Years of CSR Messages in National Geographic Magazine. Public Relations Review, 39, 491-496. https://doi.org/10.1016/j.pubrev.2013.07.003

[30] Taylor, R.E. (1999) A Six-Segment Message Strategy Wheel. Journal of Advertising Research, 39, 7-17.

[31] Lee, T., Taylor, R.E. and Chung, W. (2011) Changes in Advertising Strategies during an Economic Crisis: An Application of Taylor's Six-Segment Message Strategy Wheel. Journal of Applied Communication Research, 39, 75-91. https://doi.org/10.1080/00909882.2010.536846

[32] Golan, G.J. and Zaidner, L. (2008) Creative Strategies in Viral Advertising: An Application of Taylor's Six-Segment Message Strategy Wheel. Journal of Computer-Mediated Communication, 13, 959-972. https://doi.org/10.1111/j.1083-6101.2008.00426.x

[33] Taylor, R.E. (2005) Outside the Box, Inside the Circle: Using the Six-Segment Strategy Wheel to Predict Direction of Change in Message Strategies. National Conference of the Association for Education in Journalism \& Mass Communication, San Antonio, TX.

[34] Puto, C.P. and Wells, W.D. (1984) Informational and Transformational Advertising: The Differential Effects of Time. Advances in Consumer Research, 11, 638-643.

[35] Balmer, J.M.T. and Greyser, S.A. (2006) Corporate Marketing: Integrating Corporate Identity, Corporate Branding, Corporate Communications, Corporate Image and Corporate Reputation. European Journal of Marketing, 40, 730-741. 
https://doi.org/10.1108/03090560610669964

[36] Sicilia, M., Ruiz, S. and Munuera, J.L. (2005) Effects of Interactivity in a Web Site: The Moderating Effect of Need for Cognition. Journal of Advertising, 34, 31-44. https://doi.org/10.1080/00913367.2005.10639202

[37] Haugtvedt, C.P. and Petty, R.E. (1992) Personality and Persuasion: Need for Cognition Moderates the Persistence and Resistance of Attitude Changes. Journal of Personality and Social Psychology, 63, 308-319. https://doi.org/10.1037/0022-3514.63.2.308

[38] Moore, D.J., Harris, W.D. and Chen, H.C. (1995) Affect Intensity: An Individual Difference Response to Advertising Appeals. Journal of Consumer Research, 22, 154-164. https://doi.org/10.1086/209442

[39] Zhang, Y. and Buda, R. (1999) Moderating Effects of Need for Cognition on Responses to Positively Versus Negatively Framed Advertising Messages. Journal of Advertising, 28, 1-15. https://doi.org/10.1080/00913367.1999.10673580

[40] Batra, R. and Stayman, D.M. (1990) The Role of Mood in Advertising Effectiveness. Journal of Consumer Research, 17, 203-214. https://doi.org/10.1086/208550

[41] Petty, R.E., Cacioppo, J.T. and Schumann, D. (1983) Central and Peripheral Routes to Advertising Effectiveness: The Moderating Role of Involvement. Journal of Consumer Research, 10, 135-146. https://doi.org/10.1086/208954

[42] Meyers-Levy, J. and Malaviya, P. (1999) Consumers' Processing of Persuasive Advertisements: An Integrative Framework of Persuasion Theories. Journal of Marketing, 63, 45-60. https://doi.org/10.2307/1252100

[43] Petty, R.E., Fabrigar, L.R. and Wegener, D.T. (2003) Emotional Factors in Attitudes and Persuasion. In: Davidson, R.J., Scherer, K.R. and Goldsmith, H.H., Eds., Handbook of Affective Sciences, Oxford University Press, Oxford, 752-772.

[44] Ang, S.H. and Lim, E.A.C. (2006) The Influence of Metaphors and Product Type on Brand Personality Perceptions and Attitudes. Journal of Advertising, 35, 39-53. https://doi.org/10.1080/00913367.2006.10639226

[45] Sallam, M.A.A. (2011) The Impact of Source Credibility on Saudi Consumer's Attitude toward Print Advertisement: The Moderating Role of Brand Familiarity. International Journal of Marketing Studies, 3, 63-77.

[46] Hensel, P.J. and Bruner, G.C. (1992) Scaling and Measurement: Multi-Item Scaled Measures in Sales Related Research. Journal of Personal Selling \& Sales Management, 12, 77-82.

[47] MacKenzie, S.B., Lutz, R.J. and Belch, G.E. (1986) The Role of Attitude toward the Ad as a Mediator of Advertising Effectiveness: A Test of Competing Explanations. Journal of Marketing Research, 23, 130-143. https://doi.org/10.2307/3151660

[48] Hong, J.W. and Zinkhan, G.M. (1995) Self-Concept and Advertising Effectiveness: The Influence of Congruency, Conspicuousness, and Response Mode. Psychology \& Marketing, 12, 53-77. https://doi.org/10.1002/mar.4220120105

[49] Carroll, A.B. (1991) The Pyramid of Corporate Social Responsibility: Toward the Moral Management of Organizational Stakeholders. Business Horizons, 34, 39-48. https://doi.org/10.1016/0007-6813(91)90005-G

[50] Yang, C.M. and Hsu, T.F. (2017) Effects of Skepticism about Corporate Social Responsibility Advertising on Consumer Attitude. Social Behavior and Personality: An International Journal, 45, 453-467. https://doi.org/10.2224/sbp.5788

[51] Chang, C. (2007) Diagnostic Advertising Content and Individual Differences: Testing a Resource-Matching Perspective with a Taiwanese Sample. Journal of Adver- 
tising, 36, 75-84. https://doi.org/10.2753/JOA0091-3367360305

[52] Nan, X. and Heo, K. (2007) Consumer Responses to Corporate Social Responsibility (CSR) Initiatives: Examining the Role of Brand-Cause Fit in Cause-Related Marketing. Journal of Advertising, 36, 63-74.

https://doi.org/10.2753/JOA0091-3367360204 


\section{Appendix}

\section{Need for Cognition Scale (Source: Cacioppo, Petty, \& Kao, 1984)}

For each of the statements below, please indicate whether or not the statement is characteristic of you or of what you believe. For example, if the statement is extremely uncharacteristic of you or of what you believe about yourself (not at all like you) please place a " 1 " on the line to the left of the statement. If the statement is extremely characteristic of you or of what you believe about yourself (very much like you) please place a "7" on the line to the left of the statement. You should use the following scale as you rate each of the statements below: $1=$ extremely uncharacteristic; 2 = uncharacteristic; $3=$ somewhat uncharacteristic; $4=$ uncertain; $5=$ somewhat characteristic; $6=$ characteristic; $7=$ extremely characteristic.

1. I prefer complex to simple problems.

2. I like to have the responsibility of handling a situation that requires a lot of thinking.

3. Thinking is not my idea of fun.

4. I would rather do something that requires little thought than something that is sure to challenge my thinking abilities.

5. I try to anticipate and avoid situations where there is a likely chance I will have to think in depth about something.

6. I find satisfaction in deliberating hard and for long hours.

7. I only think as hard as I have to.

8. I prefer to think about small daily projects to long term ones.

9. I like tasks that require little thought once I've learned them.

10. The idea of relying on thought to make my way to the top appeals to me.

11. I really enjoy a task that involves coming up with new solutions to problems.

12. Learning new ways to think doesn't excite me very much.

13. I prefer my life to be filled with puzzles I must solve.

14. The notion of thinking abstractly is appealing to me.

15. I would prefer a task that is intellectual, difficult, and important to one that is somewhat important but does not require much thought.

16. I feel relief rather than satisfaction after completing a task that requires a lot of mental effort.

17. It's enough for me that something gets the job done; I don't care how or why it works.

18. I usually end up deliberating about issues even when they do not affect me personally. 